\title{
Bariery eksplanacyjne w ekonomii i politologii
}

\section{Explanatory Limitations in Economics and Political Science}

\begin{abstract}
The aim of the article is to present diverse directions of methodological evolution that took place in two social disciplines: economics and political science. The source of these diametrically opposite methodological decisions, taken by the exponents of "major currents" in these disciplines, can be attributed to diverse strategies of building the identities of their respective disciplines and different perception of the nature of social sciences. Economists, having taken their set of research instruments from formal sciences, were in favour of methodological monism and constructed the identity of their discipline in opposition to other representatives of social sciences. Whereas political science (conscious of the specific character of the subject studied by social sciences) adopted the perspective of methodological dualism, which is the reason why it has been shaping its identity not in opposition to, but within the frame of one scientific field - equipped with common research methods, but focusing on different aspects of research. The article also describes present results of these diverse methodological choices: on the one hand, there is a crisis of explanatory and predictive abilities of economics, brought about by increasing formalization of applied research models; on the other hand, we can currently observe a shift towards interpretationism in political science, which focuses on decoding the meanings and motives of human actions.
\end{abstract}

Keywords: social sciences, methodology, scientific knowledge, crisis of economics, political science

\section{Wprowadzenie - cele analizy}

Celem analizy będzie prześledzenie dróg metodologicznych dwóch dyscyplin: ekonomii i nauki o polityce oraz wyciągnięcie z tych porównań pewnych wniosków, które mogą wspomóc politologię w wyborze orientacji metodologicznych sprzyjających dalszemu rozwojowi tej dyscypliny. Będziemy analizować dwie położone skrajnie względem siebie nauki społeczne z punktu widzenia opinii na temat osiągniętego przez nie poziomu rozwoju i „naukowości”. 
Ekonomia jako jedna $\mathrm{z}$ najstarszych nauk społecznych wywodząca się od Arystotelesa, na przełomie XIX i XX w. zafascynowała się osiągnięciami teoretycznymi tzw. nauk ścisłych, czyli przede wszystkim osiągnięciami matematyki, a później również fizyki, chemii i biologii. Przyjęcie standardów metodologicznych tych nauk stało się dla wielu ekonomistów zadaniem priorytetowym. Pewną przeszkodą na tej drodze było to, że ekonomia jako nauka społeczna nie mogła się całkowicie odciąć od własnego przedmiotu badań, ale mogła ogłosić swą wyjątkowość względem pozostałych nauk społecznych. Większość ekonomistów przyjęła założenie, że ekonomię wyróżnia to, że ma ona własną metodologię, odmienną od tej, którą akceptowała zdecydowana większość reprezentantów pozostałych nauk społecznych. Ta deklaracja o wyjątkowości wystarczyła, aby większość ekonomistów z satysfakcją przyjęła, a w rzeczywistości zaczęła głosić, że „ekonomia jest królową nauk społecznych”. Jako taka przestała się ona interesować rezultatami dokonań warsztatowych pozostałych nauk społecznych, ale jednocześnie jej metody i techniki badawcze budziły uzasadnione zainteresowanie, co nie pozostało bez wpływu na rozwój innych nauk społecznych. Politolodzy i socjolodzy natomiast chętnie adaptowali np. teorię racjonalnego wyboru, instytucje rynku czy marketing, ale nie traktowali tych elementów jako substytutów własnego warsztatu. Wielu liczących się ekonomistów w dalszym ciągu utrzymuje, że ekonomia powinna starać się utrzymać swą odrębność metodologiczną w stosunku do pozostałych nauk społecznych. Przykładowo Don Ross „ostrzega, że przyjęcie hiperempirycystycznych zasad metodologicznych grozi osłabieniem ekonomii jako dyscypliny i przekształceniu jej w część stosowanej psychologii społecznej" (Wojtyna, 2009, s. 33).

Poza tym niektórzy ekonomiści uznali przewagę ekonomii nad innymi naukami społecznymi, a to upoważniło ich do obejmowania swymi badaniami niemal całego przedmiotu badań tych nauk, tj. politologii, socjologii, psychologii, antropologii itd. Wierzyli oni, że dobre rezultaty można uzyskać tylko, stosując narzędzia i logikę ekonomiczną. To zjawisko określono w literaturze jako „imperializm ekonomiczny", a polega on na przekonaniu, że instrumentarium i teoria ekonomiczna są najlepszym sposobem poznania zachowania ludzi. Zatem należy istotnie rozszerzyć przedmiot badań ekonomicznych. Tego typu poglądy były wprawdzie krytykowane przez metodologów i wielu ekonomistów, były też krytycznie przyjmowane przez badaczy społeczeństwa, ale nie zahamowało to procesu zawłaszczania nauk społecznych przez ekonomię.

Imperializm danej nauki nie jest tylko domeną ekonomistów. Przekonanie, iż dana nauka społeczna jest szczególnie predysponowana do wyjaśniania zjawisk społecznych, przytrafiało się też socjologom czy psychologom. Na przykład Vilfredo Pareto twierdził, że ekonomia to część socjologii. Podzielił on zatem poglądy Augusta Comte’a, twórcy nazwy „socjologia”, który był przekonany, 
że w jej ramach będzie możliwa unifikacja wiedzy o społeczeństwie (Brzeziński, Gorynia, Hockuba, 2009, s. 221-222).

Z kolei politologia była i jest dyscypliną, której uwikłanie w wartości jest raczej bezsporne. Co więcej, widoczne są też jej związki z ideologiami. Problem monizmu metodologicznego nie jest $\mathrm{w}$ zasadzie rozpatrywany przez politologów. Politologia jest nauką społeczną i żaden z politologów nie kwestionuje tego faktu, a to ma swoje konsekwencje - wyrażają się one w tym, że nie da się świata ludzkiego wyjaśnić za pomocą aparatu pojęciowego i standardów metodologicznych stosowanych w naukach przyrodniczych. Jak pisze Kazimierz Sosenko, ze względu na odmienną ontologię w naukach społecznych „kontekst uzasadnienia nie może być taki sam jak w naukach przyrodniczych, a dualizm metodologiczny jest wyłącznie reakcją na niemożność uzyskania empirycznych danych o takich przedmiotach niematerialnych jak sensy, znaczenia, wartości” (2001, s. 18).

W politologii zatem należy się koncentrować $\mathrm{w}$ znacznie większym stopniu na „rozumieniu”, bowiem w grę wchodzą tutaj zupełnie inne rodzaje relacji, relacje związane ze świadomością, które nie są empirycznie potwierdzalne, są niewidoczne, uwikłane w kontekst kulturowy. Politolodzy muszą zatem bardziej zwracać się w kierunku interpretacjonizmu, który propaguje narracyjną formę wyjaśniania i który narrację w politologii przyrównuje do roli teorii w naukach przyrodniczych (Bevir, Rhodes, 2006, s. 134).

Te odmienne drogi metodologiczne, którymi podążały ekonomia i politologia, zasługują na przeanalizowanie, porównanie i wyciągnięcie wniosków.

\section{Struktura wiedzy}

Analizę rozpoczniemy od wskazania kilku fundamentalnych problemów metodologicznych, które dotychczas nie zostały rozstrzygnięte i które raczej nie będą rozwiązane również w przyszłości, a jako takie umożliwiają badaczom dokonywanie eklektycznego wyboru komponentów metodologicznych. Pierwszy zasadniczy problem stwarza sama istota „nauki”. Mimo wielu podejmowanych prób nie udało się dotąd dokonać precyzyjnego rozdziału "nauki” od "nie-nauki”. W esencjalizmie, który dominował aż do XIX w., a który wywodzi się od Platona i Arystotelesa, nauka sprowadzała się do obserwacji pojedynczych zdarzeń po to, aby uchwycić metodą indukcji wszystkie wspólne cechy obserwowanych zdarzeń, cechy decydujące o ich „istocie" i na tej podstawie sformułować ich definicję. Bertrand Russell, uznając, że świat jest poznawalny tylko w ograniczonym stopniu, dowodził, że różnica między realną nauką a codziennym poznaniem jest trudna do rozgraniczenia, bowiem w nauce stosuje się nie tylko zasady matematyki, ale i niejasne reguły interpretacji. Według zasady weryfikowalności, 
którą sformułowało Koło Wiedeńskie, wszelkie twierdzenia dzielą się na: analityczne, czyli prawdziwe na mocy definicji własnych terminów, oraz syntetyczne, czyli prawdziwe lub fałszywe na mocy praktycznego doświadczenia. Z kolei Karl Popper starał się wykazać, że dzięki nowym kryteriom demarkacji można rozłącznie podzielić wszelką ludzką wiedzę na „naukę" i „nie-naukę”. Nauka według Poppera jest systemem syntetycznych twierdzeń o realnym świecie, które mogą być sfalsyfikowane przez obserwację empiryczną. Cechą nauki jest wg niego metoda formułowania i sprawdzania twierdzeń, a nie przedmiot zainteresowania czy dążenie do wiedzy pewnej. Według Isaaca Newtona celem nauki jest nie tyle opis, co odkrycie praw uniwersalnych, które pozwalają przewidzieć, jak rzeczy zachowują się w różnych okolicznościach. Mark Blaug z kolei pisze o całym spektrum wiedzy. Spektrum, którego krańcami są z jednej strony „twarde” nauki przyrodnicze w rodzaju fizyki i chemii, a z drugiej - poezja, sztuki piękne i krytyka literacka. Środek tego spektrum zajmują "nauki bardziej miękkie”, takie jak biologia, kosmologia i nauki społeczne, które dobrze by było, gdyby były bliższe „nauki” niż „nie-nauki” (1995, s. 48, 49, 172). Bardziej rozbudowaną strukturę wiedzy proponują Jan Such i Małgorzata Szcześniak, którzy wyróżnili: wiedzę potoczną, wiedzę naukową, wiedzę artystyczno-literacką. Ponadto wyżej wymienieni autorzy wydzielają wiedzę spekulatywną oraz wiedzę irracjonalną, nieuchwytną dla rozumu, poza-doświadczalną (2006, s. 37-43).

Ten lapidarny przegląd stanowisk potwierdza, iż struktura naszej wiedzy jest różnie konceptualizowana, a ponadto że nie można przeprowadzić rozdzielnego jej podziału, a skoro tak, to należy zakładać wzajemne przenikanie się czy przesuwanie się niektórych fragmentów wiedzy w ramach spektrum wiedzy ogólnej. Rozwój nauki mierzony może być zatem wielkością zasobów i tempem przemieszczania się poszczególnych rodzajów wiedzy w kierunku wiedzy naukowej.

$$
\text { <--------------------- ogólny kierunek przemieszczenia wiedzy }
$$

\begin{tabular}{|c|c|c|c|}
\cline { 2 - 3 } \multicolumn{4}{c|}{ Wiedza potoczna o przyrodzie i społeczeństwie } \\
\hline $\begin{array}{c}\text { Wiedza naukowa } \\
\text { o przyrodzie } \\
\text { i społeczeństwie }\end{array}$ & $\begin{array}{c}\text { Wiedza } \\
\text { artystyczno-literacka }\end{array}$ & $\begin{array}{c}\text { Wiedza } \\
\text { spekulatywna }\end{array}$ & $\begin{array}{c}\text { Wiedza } \\
\text { irracjonalna }\end{array}$ \\
\hline
\end{tabular}

Rysunek 1. Struktura wiedzy ogólnej

Źródło: opracowanie własne. 
Struktura wiedzy począwszy od XIX w. dynamicznie się zmienia. Postęp wyraża się w tym, że to, co było nieobserwowalne, staje się obserwowalne, i to, co było niemierzalne, staje się możliwe do oszacowania, a to, co było szacunkowe, staje się mierzalne. Zasoby wiedzy naukowej powiększają się, bowiem nauka czyni przedmiotem swych badań to, co było wcześniej zasobem wiedzy potocznej, wiedzy artystyczno-literackiej, wiedzy spekulatywnej czy irracjonalnej (rysunek 2).

\begin{tabular}{|l|l|l|l|c|}
\hline \multicolumn{4}{|c|}{ Nauki stawiające na „wyjaśnianie” } & Sztuka \\
\hline Nauki formalne $\begin{array}{c}\text { Nauki przyrod- } \\
\text { nicze „twarde” }\end{array}$ & $\begin{array}{l}\text { Nauki przyrod- } \\
\text { nicze „miękkie” }\end{array}$ & Nauki społeczne & \multicolumn{3}{|c|}{ Nauki nastawione na „rozumienie” } \\
\hline
\end{tabular}

Rysunek 2. Struktura szeroko rozumianej nauki (science i art)

Źródło: opracowanie własne.

Tylko nauki formalne (matematyka i logika) mają pełną szansę stosowania w wyjaśnianiu schematu dedukcyjno-nomologicznego (D-N). Nauki przyrodnicze "twarde" mają już z realizacją tego schematu pewne trudności, bowiem eksplanans powinien być tekstem prawdziwym, a takiej pewności nie mamy. Co więcej, wiemy że prawdziwość eksplanansu często nie była spełniona. Historia nauki potwierdza, że niemal wszystkie prawa nauki podawano w wątpliwość. Z wymogu prawdziwości należało więc zrezygnować i zastąpić go wymogiem, aby eksplanans był wiarygodny albo sprawdzalny i dobrze potwierdzony empirycznie. Carl Hempel nakłada ponadto na poprawne eksplanacje warunek „istotności”, co z kolei rodzi pytanie o to, co ma decydować o istotności itd. (Mejbaum, 1995, s. 8-12). Nic więc dziwnego, że nauki przyrodnicze, zarówno te „twarde”, jak i przede wszystkim „miękkie”, tłumacząc, muszą sięgać po schemat wyjaśniania probabilistycznego, a niektóre nauki przyrodnicze muszą się zadawalać zaledwie funkcją „rozumienia”. W naukach społecznych ze względu na odmienną ich ontologię w grę wchodzą bowiem nie tylko rzeczy, ale i przedmioty niematerialne, takie jak: sensy, znaczenia i wartości, wykorzystywanie przez nie wyłącznie schematów interpretowania typowych dla nauk przyrodniczych (D-N) i wyjaśniania probabilistycznego byłoby rażącym zawężeniem ich funkcji. Dlatego Wilhelm Dilthey opowiedział się za metodą hermeneutyczną jako ważną dla nauk o kulturze. Nauki społeczne nie mogą zrezygnować z poznania wytworów kultury zarówno tych obiektywnych, jak i tych, które są przeżyciami psychicznymi. Nie mogą się one ograniczyć do wnioskowania na podsta- 
wie przyczyny, lecz muszą badać stosunki zachodzące między ekspresjami życia i rozpatrywać poszczególne zjawiska jako element całości (Sosenko, 2001, s. 18). Roli nauk społecznych nie można zatem sprowadzić li tylko do budowania teorii dedukcyjnych, ich powołaniem jest przede wszystkim świadczenie pomocy w zrozumieniu treści wytworów kultury.

Kolejny problem $\mathrm{w}$ doborze metodologicznych komponentów stwarza badaczom sama istota "teorii”. Z techniczno-metodologicznego punktu widzenia teoria naukowa, pisze Wacław Mejbaum, jest zawsze prawdziwa abstrakcyjnie, jeżeli tylko nie jest wewnętrznie sprzeczna. Stąd w nauce muszą istnieć alternatywne teorie, ale nie wykluczają się one nawzajem ani jako prawdy abstrakcyjne, ani jako prawdy konkretne (Mejbaum, 1995, s. 53, 59). Skoro nie ma możliwości wykazania prawdziwości teorii empirycznych, to tak długo, aż nie zostaną one sfalsyfikowane, zarówno prawa, jak i teorie pozostają hipotezami przyjętymi tymczasowo (Such, Szcześniak, 2006, s. 22-23). Kolejnym argumentem przemawiającym za dużą dowolnością interpretacyjną jest różnie interpretowany status poznawczy teorii. Najstarsze stanowisko przypisywało „teorii” wartość logiczną, tzn. że można było orzekać o niej w kategoriach: prawda, fałsz. Inne stanowisko sprowadzało teorię do pewnych zasad, czy reguł analizy danych empirycznych bądź reguł wnioskowania. Wreszcie według trzeciej koncepcji teorię zwolniono $z$ roli eksplanacyjnej na rzecz realizacji funkcji deskryptywnej, tzn. opisu relacji zachodzących między obserwowalnymi zdarzeniami czy zjawiskami (Such, Szcześniak, 2006, s. 75).

Na podstawie różnie definiowanego statusu teorii powstały różne jej koncepcje, takie jak: instrumentalistyczna, konwencjonalistyczna czy realistyczna.

Kolejny pretekst do subiektywnego traktowania metodologii stanowią trudności w precyzyjnym oddzieleniu „faktów” od „wartości”. Już w XVIII w. D. Hume dowodził, że „jest” i „nie jest” wywodzą się z całkowicie odmiennych relacji niż „powinno się" $i$,nie powinno się", a zatem na podstawie tego co ,jest” nie można wnioskować o tym co „powinno być”. Max Black nazwał to „gilotyną Hume'a”. Ale nie wszyscy zgadzają się ze stanowiskiem, że z nauki da się wyprowadzić moralność, bowiem w rzeczywistości sądy typu „powinno się" powstają pod przemożnym wpływem sądów typu „jest”, i że nasze wartości zależą od przekonań o charakterze rzeczowym. Na przykład według M. Blauga nie istnieją żadne empiryczne opisowe opinie typu ,jest” uważane za prawdziwe, które nie opierają się na określonym porozumieniu społecznym (1995, s. 179-180). Możliwość istnienia wolnych od wartości nauk społecznych głosił Max Weber, chociaż jednocześnie nie zaprzeczał on, iż w rzeczywistości nauki społeczne pełne są politycznych przesądów.

Zwolennicy nauki społecznej uwolnionej od wartości stoją na stanowisku, że różnice między sądami metodologicznymi (o faktach) a sądami wartościu- 
jącymi są różnicami rodzajowymi. Oponenci, którzy nie widzą możliwości jakiejkolwiek wolnej od wartości „obiektywnej nauki społecznej”, różnice te sprowadzają do stopnia, a nie do rodzaju. Radykalni oponenci wręcz stwierdzają, że absolutnie wszystkim twierdzeniom o zjawiskach społecznych brakuje obiektywności, gdyż są przesycone wartościami. Subiektywnemu wybieraniu opcji metodologicznych sprzyjają też inne płaszczyzny sporów, a mianowicie: spór między indywidualizmem a holizmem metodologicznym; spór między monizmem metodologicznym a doktryną Verstehen oraz spór o znaczenie indukcjonizmu i hipotetyzmu itd.

Wszystkie te płaszczyzny nierozstrzygniętych wyborów metodologicznych nie pozwalają na jednoznaczne oceny postępowań badawczych i relatywizują wybory rozwiązań metodologicznych.

\section{Credo metodologiczne głównych nurtów ekonomii}

Od samego początku, tzn. od czasu, gdy ekonomia stała się autonomiczną dyscypliną, daje się zauważyć zorientowanie ekonomistów na nauki przyrodnicze. Już Adam Smith podjął próbę zastosowania newtonowskiej metody w ekonomii. David Ricardo był zdecydowanym rzecznikiem tego, co dziś określamy mianem „hipotetyczno-dedukcyjnego modelu wyjaśniania” oraz bezpośredniego odnoszenia abstrakcyjnych modeli ekonomicznych wprost do realnego świata (Blaug, 1995, s. 99-100).

Francuski ekonomista Jean-Baptiste Say stał na stanowisku, że ekonomia jest nauką teoretyczną i podobnie jak nauki przyrodnicze badającą i uogólniającą jedynie to, co jest. Założenia polityczno-gospodarcze natomiast jej nie dotyczą i muszą być od niej zdecydowanie oddzielone. Rozdzielał on konsekwentnie ekonomię polityczną od polityki gospodarczej zgodnie z jego podziałem ekonomii na ekonomię nomologiczną i normatywistyczną. Podobne stanowisko prezentował William Nassau Senior, dla którego również ekonomia była nauką nomologiczną, niemającą żadnego związku z postulatami politycznymi. Przedmiotem badań ekonomii miało być według niego bogactwo, na które składały się zarówno materialne, jak i niematerialne środki zaspokajania potrzeb ludzkich. Subiektywne traktowanie zjawisk ekonomicznych przez W. Nassau Seniora pozwala sądzić, iż był on inspiratorem powstałego później kierunku ekonomii subiektywistycznej (Spychalski, 2001, s. 134, 138). John Stuart Mill, tworząc model homo economicus miał świadomość, że nie jest to model człowieka realnego, lecz fikcyjnego. Mimo tego po pewnym czasie wielu ekonomistów zaczęło traktować ten model jako dobrze opisujący rzeczywistość. Prawa ekonomiczne ujmował on jako reguły niezmienne pozostające w ścisłej analogii do praw przy- 
rody. Człowiek jako jednostka z natury egoistyczna w swym działaniu podlega takim samym prawom jak przyroda. Ekonomię polityczną traktował J.S. Mill jako naukę z gruntu abstrakcyjną, która posługuje się metodą a priori, czyli wyprowadzania wniosków z hipotezy, co do której zakłada się, że jest prawdziwa. Mill opowiedział się za monizmem metodologicznym, ale jednocześnie przyznał, że cztery kanony indukcji nie znajdują zastosowania w naukach społecznych (Blaug, 1995, s. 113).

Z kolei dla Johna Nevillea Keynesa (seniora) introspekcja to oparte na empirii źródło przesłanek ekonomicznego rozumowania, a koncepcja człowieka ekonomicznego stanowi abstrakcję „człowieka realnego”, a nie „człowieka fikcyjnego", w ówczesnych już bowiem warunkach motywem dominującym, wpływającym na zachowania ekonomiczne nie jest altruizm czy bezinteresowność, lecz własny interes. Po teorii ekonomicznej, jego zdaniem, nie należy się spodziewać bezpośrednich prognoz - teoria bowiem stanowi „motor analizy”, którego zastosowaniu towarzyszyć powinno szczegółowe badanie istotnych „przyczyn zakłócających" (Blaug, 1995, s. 127-129).

Jak łatwo zauważyć, wśród klasyków i ich kontynuatorów czy interpretatorów nie było zgodności w sprawach metodologicznych. Rozbieżności mnożyły się, mimo że podzielali oni pewne poglądy na gospodarowanie i naukę ekonomii a kojarzeni są przede wszystkim z tymi, którzy głosili potęgę i prymat dedukcji oraz rozumowania a priori. Zdecydowanie różne poglądy w stosunku do ekonomii klasycznej prezentował nurt tzw. historyzmu, który swe korzenie wywodzi z kręgu kultury niemieckiej. Za pierwsze ogniwo tego nurtu uznawany jest Adam Heinrich Müller, który stanął na stanowisku nierozerwalnego związku zjawisk ekonomicznych i politycznych z moralnymi. Teza ta stała się inspiracją do powstania sto lat później normatywnego kierunku ekonomii.

W Niemczech w XIX w., począwszy od lat 40. aż do 60., rozwijała się starsza szkoła historyczno-metodologiczna, którą reprezentowali Wilhelm Roscher, Bruno Hildebrand, Karl Knies. Zakwestionowali oni głoszoną przez klasyków obiektywność praw ekonomicznych i tezę o powszechnej mocy ich obowiązywania. Nie ma ich zdaniem praw, które powszechnie mogłyby rządzić zjawiskami ekonomicznymi czy społecznymi. Prawa należy rozważać zawsze konkretnie, czyli z uwzględnieniem miejsca i czasu ich obowiązywania. Wszyscy negowali możliwość odkrycia przez ekonomię praw przyczynowo-skutkowych. Różnili się tylko co do możliwości sformułowania praw rozwojowych. Tak ujęta ekonomia byłaby zatem nauką historyczną, której zadaniem byłby dokładny opis bieżącej rzeczywistości. Należy badać fakty, obserwować przejawy życia gospodarczego, korzystać z danych statystycznych i historycznych i unikać badań abstrakcyjnych, które nie mogą oddać rzeczywistości. Bruno Hildebrand uznawał tylko metodę indukcji za możliwą do wykorzystania w ekonomii i stąd zale- 
cał prowadzenie w tej dziedzinie badań idiograficznych, a nie nomologicznych. Ewentualne prawidłowości w działaniach gospodarczych mogą wynikać z przypadkowych analogii czy podobieństw w rozwoju jednego czy drugiego narodu. Ekonomię według B. Hildebranda trudno wyodrębnić z całości, którą stanowi nauka o kulturze danego narodu. Istnieją też niewielkie różnice między ekonomią a historią gospodarczą (Spychalski, 2001, s. 169-175).

Jak łatwo się zorientować, zarówno klasycy, jak i przedstawiciele starszej szkoły historycznej stworzyli szeroki zbiór idei metodologicznych, który umożliwia powoływanie się na nich wszystkim bez mała przedstawicielom nowożytnych kierunków ekonomicznych. Sformułowali oni bowiem dostatecznie dużo argumentów „za” i „przeciw”, co oznacza, że inspiracji w ich twórczości mogą szukać zarówno zwolennicy monizmu metodologicznego, jak i ich przeciwnicy, zwolennicy nie tylko indywidualizmu metodologicznego, ale także holizmu, zwolennicy modelowania, dedukcjonizmu, indukcjonizmu, czy też nawet koncepcji Verstehen, czyli „rozumienia”.

Generalnie, klasycy ekonomii kojarzeni są przede wszystkim z tymi, którzy głosili potęgę i prymat dedukcji i rozumowania a priori ${ }^{1}$. Nie sposób prześledzić całej historii rozwiązywania problemów metodologicznych przez ekonomię. Skoncentrujemy zatem naszą uwagę tylko na szkołach najważniejszych, tj. na tych, które współcześnie mają swoich przedstawicieli i oddziałują na kierunki i metody badań ekonomicznych.

Ekonomia neoklasyczna zaczęła się rozwijać dopiero wówczas, gdy sformułowana została teoria użyteczności krańcowej i od kiedy na teorii produktywności krańcowej kapitału i pracy zaczęto opierać ceny czynników wytwórczych i mikroekonomiczną teorię przedsiębiorstwa (Nasiłowski, 2003, s. 64). Koncepcja ekonomii neoklasycznej narodziła się w trzech szkołach: austriackiej, nazywanej też wiedeńską bądź psychologiczną, zainicjowanej przez Carla Mengera; lozańskiej, zwanej inaczej matematyczną, zapoczątkowanej przez Leona Walrasa; manchesterskiej, za faktycznego jej założyciela uznano Alfreda Marshalla (Bartkowiak, 2011, s. 21).

Alfred Marshall podjął się przełożenia dorobku D. Ricardo i J.S. Milla na język matematyki po to, aby go wykorzystać do analizy rynku, konsumenta i producenta. Jego celem było stworzenie czystej nauki, czyli teorii ekonomii wolnej od wartościowania. Aby podkreślić ten charakter, zaproponował zmianę nazwy „ekonomii politycznej” na termin „Economics”, czyli „ekonomika” (Nasiłowski, 2003, s. 67). Mimo że Marshall był matematykiem, odrzucił w ekonomii moż-

Lionel Robbins uznawał ekonomię za naukę neutralną w odniesieniu do celów polityki ekonomicznej, a pogląd, iż jednostki potrafią uporządkować swoje preferencje, traktował jako analityczną prawdę o charakterze a priori (Blaug, 1995, s. 130). 
liwość wykrycia związków przyczynowo-skutkowych na rzecz funkcjonalnych powiązań zjawisk ekonomicznych. Takie funkcjonalne potraktowanie ekonomii miało zarówno dobre, jak i złe strony - było pewnym spłyceniem analizy, ale pozwalało lepiej, szerzej rozumieć ekonomię. Nie traktował on ekonomii jako logiki czystej i nauki formalnej po to, aby nie straciła ona kontaktu z rzeczywistością i aby stanowiła studium ludzkości w zwyczajnym życiu i prowadzeniu interesów. Zrezygnował z mierzenia bezpośredniego samych procesów psychicznych człowieka, lecz zalecał, aby o nich wnioskować pośrednio z ich skutków. Prawa ekonomiczne traktował Marshall jako pewne tendencje, ku którym zmierzają relacje między wielkościami ekonomicznymi w danych warunkach. W zgodzie ze szkołą klasyczną prawa ekonomiczne pojmował on jako obiektywne, tzn. niezależne od woli ludzi (Spychalski, 2001, s. 241). Jako pierwszy zastosował on metodę ceteris paribus, założył bowiem, że w realnej gospodarce wszystkie zjawiska są ze sobą ściśle powiązane i wzajemnie na siebie oddziałują. Chcąc wypreparować jeden tylko typ związku, należy badanie przeprowadzić w pewnej izolacji od pozostałych czynników, podobnie jak czynią to matematycy czy fizycy (Nasiłowski, 2003, s. 68). Marshall zaproponował nowe podejście badawcze polegające na braku rozdziału czynników popytowych i podażowych. Postulował ujęcie popytowo-podażowe w skali mikro, czyli badanie wpływu danej ceny na popyt na określone dobro. W sferze zainteresowań badawczych powinien być rynek konkretnego dobra i równowaga na tym rynku, czyli równowaga cząstkowa. Szkoła manchesterska, koncentrując się na badaniu wybranego rynku i warunków równowagi cząstkowej, pomijała wydarzenia, jakie zachodziły na innych rynkach, mimo iż w rzeczywistości wszystkie one wzajemnie na siebie oddziałują. Zabieg polegający na badaniu wyodrębnionego rynku konkretnego dobra oznacza, iż badający redukuje zmienne do niewielkiej liczby, najczęściej do dwóch. Zależność taką ująć można w wykres geometryczny, jeżeli natomiast liczba zmiennych jest zbyt duża, to wykorzystuje się analizę matematyczną (Lange, 1975a, s. 65-66).

Z kolei szkoła matematyczna (lozańska) uznawana jest przez ekonomistów za tę, która rozwinęła koncepcję sformalizowania ekonomii. Nie była bynajmniej pierwszą $\mathrm{w}$ tej dziedzinie, ale z pewnością w głównej mierze przyczyniła się do tego, że „matematyzacja ekonomii” objęła prawie wszystkie kierunki poczynając od połowy XX w. Pod wpływem twórców tej szkoły: Leona M. Walrasa, Vilfreda Pareto i Enrica Barone’a, ekonomia stawała się czystą logiką gospodarowania, nauką formalną, odległą nawet od nauk przyrodniczych. Taka nauka nie mogła mieć odniesienia zarówno do polityki ekonomicznej, jak i do wszelkiej praktyki, nie mogła zawierać ekonomii stosowanej ani socjologii. Podstawowe założenie tej szkoły mówiło, iż wszystkie zjawiska i procesy ekonomiczne łączą się ze sobą. Zakładano też, że jedno zjawisko jest przyczyną czy skutkiem innego zjawiska, a wszystkie są ze sobą sprzężone na zasadzie funkcji matematycznych. 
Określenie: $\mathrm{Y}$ jest funkcją X nie oznacza, iż X jest przyczyną $\mathrm{Y}$. W tej sytuacji zadaniem ekonomii nie jest wykrywanie związków przyczynowo-skutkowych, a zależności funkcyjnych. W tak zaprogramowanej ekonomii nie widziano miejsca dla elementów psychologicznych czy subiektywnych. Zadaniem ekonomii było poszukiwanie równowagi za pomocą właściwego systemu równań matematycznych z odpowiednią liczbą niewiadomych. Rezultatami tych zabiegów mogły być jedynie modele, a nie wyjaśnianie rzeczywistości. Dane wprowadzane do modelu mogły mieć charakter danych prawdopodobnych, szacunkowych, a niektóre wręcz charakter wielkości niewymiernych, dlatego słusznie kwestionowano możliwości wykorzystania wynikających z nich informacji do podejmowania decyzji (Spychalski, 2001, s. 232-233).

Szkołę matematyczną krytykowano za odrywanie się od analizowania rzeczywistości i za przyjmowanie nierealistycznych założeń. Próbowała się ona bronić, wprowadzając do swych modeli cele społeczne. Nie potrafiła jednak za pomocą tych kosmetycznych zabiegów zmienić swego charakteru, który najłatwiej opisać, przytaczając zestaw podstawowych założeń przez nią przyjętych. Mianowicie L. Walras w roku 1874, budując sformalizowany model matematyczny gospodarki w stanie równowagi ogólnej, przyjął założenia, które w rzeczywistości nie mogły być spełnione: gospodarka składa się z dwóch sektorów przedsiębiorstw i gospodarstw domowych, nie ma w niej sektora państwowego i handlu zagranicznego, technika i technologia produkcji w przedsiębiorstwach okazują się constans, zatrudnienie jest pełne, przedsiębiorstwa działają w warunkach prawdziwej konkurencji, istnieje doskonała mobilność czynników produkcji, wytworzone dobra są homogeniczne rodzajowo, podmioty gospodarcze dysponują pełną informacją, gospodarstwa domowe przy stałych dochodach i niezmiennych preferencjach zgłaszają popyt na dobra konsumpcyjne w rozmiarach określonych przez sumę wszystkich dochodów (Nasiłowski, 2003, s. 69-70).

Nic więc dziwnego, że przy takich założeniach model nie stwarzał szans na praktyczne jego wykorzystanie, chociaż nie można zakwestionować, że ten bardzo złożony i abstrakcyjny model, uwzględniający prawie wszystkie istotne czynniki, mógł być przydatny w nauczaniu ekonomii i stanowić inspirację do konceptualizacji nowych kierunków rozwoju myśli ekonomicznej. Mieli tego świadomość nawet twórcy szkoły matematycznej, bowiem zaczęli poszukiwać możliwości w ramach innych kierunków badawczych, mianowicie E. Barone zaczął upatrywać możliwości zastosowania swoich modeli w gospodarce socjalistycznej, która, jak dowodził Oskar Lange, bardziej niż kapitalistyczna nadawała się do wykorzystania modeli matematycznych (Lange, 1977a, s. 26-27).

Za całkowicie odmienną koncepcją rozwoju ekonomii na początku lat 70 . XIX w. opowiadała się europejska kontynentalna szkoła wiedeńska, którą poza C. Mengerem reprezentowali: Eugen von Böhm-Bawerk i Friedrich von Wie- 
ser. Zaliczana do szkół subiektywnych zmierzała ona do sprowadzenia ekonomii do psychologii. Nie odgrywała takiej roli jak szkoły wcześniej przedstawione, jak się bowiem okazało, była zbyt eklektyczna. Łączyła czynniki obiektywne z subiektywnymi i odrywała sferę psychiki ludzkiej od kontekstu życia społecznego. Przykładowo za wartość proponowała uważać subiektywnie odczuwaną użyteczność przez podmiot nabywający towar. Czyli o wartości towaru głównie miało stanowić to, czy i w jakiej mierze jest on pożądany przez konsumenta lub producenta. A więc ten sam towar miałby w zależności od tego, w czyich rękach się znajduje oraz w odmiennym czasie i innej przestrzeni różną wartość. Szkoła ta wprowadziła pojęcie użyteczności krańcowej oraz zmierzała do formułowania praw. Przykładowo jej podstawą ekonomiczną stało się prawo Gossena, zgodnie z którym w miarę zwiększania konsumpcji danego dobra maleje zadowolenie z niego. Typową teorią szkoły wiedeńskiej była teoria użyteczności krańcowej oparta na mało realnym założeniu o mierzalności użyteczności subiektywnie pojmowanej i mierzalności zjawisk psychologicznych (Spychalski, 2001, s. 223-227, 231). Szkołę tę zmodyfikowali jej wychowankowie - Ludwig von Mises i Friedrich August von Hayek, którzy atakując „scjentyzm”, czyli metodologiczny monizm, stworzyli nowoczesną szkołę austriacką. Mises, konstruując ogólną teorię racjonalnego działania, założył, że będzie można dzięki niej wyjaśnić nie tylko zachowania w sferze gospodarowania, ale także każde zachowanie jednostki. Uczynił z tego niewymagającą dodatkowego uzasadnienia syntetyczną zasadę a priori.

Generalnie szkoła austriacka opowiadała się za wolnym rynkiem, za niskimi, a nawet zerowymi podatkami, za powrotem do standardów złota, za likwidacją systemu rezerw cząstkowych i banku centralnego. Chcieli też wyeliminować ingerencję państwa ze sfery gospodarczej. Jej przedstawiciele wskazywali na destrukcyjną rolę prawa stanowionego, które nie powinno zastępować praw ekonomicznych. Ekonomia według tej szkoły nie jest nauką o rzeczach, lecz nauką o ludziach, o ich zamiarach i działaniach. Granice ekonomii nie są wytworem materialnych obiektywnych czynników, lecz są stanowione przez „przedsiębiorczość, przez ludzką wiedzę. $Z$ tego powodu krytykowano budowanie modeli matematycznych zjawisk i procesów ekonomicznych, bowiem te nie mogły uwzględnić roli przedsiębiorczości, pomijały zjawisko czasu oraz opierały się na zdezaktualizowanej informacji. Tworzenie zatem modeli matematycznych wydawało się mało przydatne, ponieważ pozwalają one przewidzieć trendy lub zachowania, ale ich weryfikacja empiryczna okazuje się bezcelowa. Sprzeciwiano się też dzieleniu ekonomii na mikroekonomię i makroekonomię i przeprowadzaniu eksperymentów przez nauki społeczne (Kaczmarczyk, 2017, s. 4).

Krytyczny wobec ekonomii klasycznej, a właściwie wobec ekonomii neoklasycznej był John Maynard Keynes. Do jego twórczości nawiązują niemal wszy- 
scy ówcześni, jak i współcześni ekonomiści. Kontrowersje budzi już sam charakter „ogólnej teorii zatrudnienia procentu i pieniądza”. Dla jednych jest to teoria, ale dla innych raczej zbiór postulatów praktycznego podejścia do życia gospodarczego. Po kryzysie lat 1929-1933 argumentacja na rzecz interwencjonizmu państwa w gospodarkę trafiła na właściwy grunt, gdyż zarówno ten kryzys, jak i poprzednie godziły w liberalizm i te kierunki ekonomii, które kryzysy gospodarcze sprowadzały do przypadkowych faktów naruszania równowagi ekonomicznej (Wojtyna, 2000, s. 68-69). Keynes ujmował ekonomię jako dział logiki i jako sposób myślenia, był też przeciwnikiem traktowania jej jako nauki pseudoprzyrodniczej. Uważał, że głównym zadaniem ekonomii jest tworzenie modeli oraz wypracowanie procedur takiego ich wyboru, aby odpowiadały one realiom. Stwierdzał, że ekonomia to nauka $\mathrm{z}$ gruntu etyczna, a nie przyrodnicza i m.in. dlatego $\mathrm{z}$ dużym sceptycyzmem odnosił się do ekonometrii (Blaug, 1995, s. 133).

W naszym przeglądzie głównych idei metodologicznych lansowanych przez najważniejsze $\mathrm{w}$ historii kierunki ekonomii za konieczne uznaję uwzględnienie tzw. socjalizmu rynkowego, czyli modelu O. Langego (Temkin, 2008, s. 46). System ten został przez Langego zdefiniowany w tak normatywny sposób, iż stopniem oderwania od rzeczywistości znacznie przewyższał model Walrasa. Jako taki model teoretyczny miał naturalną przewagę nad innymi systemami, które chociażby częściowo odnosiły się do rzeczywistości, i stąd stwarzał znacznie większe możliwości wykorzystania osiągnięć matematyki (Lange, 1977b, s. 33-37). Lange mógł więc wydzielić tzw. dedukcyjną część ekonomii politycznej opartej na połączeniu dedukcji i indukcji oraz pozostałą jej część, która bazowała na połączeniu indukcji i redukcji (Lange, 1975b, s. 341-352). Dedukcyjna część ekonomii, jako nauka czysta, rzeczywiście bardziej przypominała dział matematyki i niewiele miała wspólnego z jakąkolwiek nauką społeczną.

Jak można zauważyć, od samego początku, od szkoły klasycznej, poprzez rewolucję marginalistyczną, socjalizm rynkowy, ignorowanie teorii uwzględniających wartości i eklektyzm metodologiczny, konsekwentnie zmierzano, bez liczenia się ze skutkami tych działań, do narzucenia głównemu nurtowi badań ekonomicznych charakteru nauki zbliżonej do statusu nauk przyrodniczych. Wymagało to odpowiedniego przedefiniowania ekonomii. Przedefiniowania, które położy akcent na kalkulacji i optymalizacji. Taką definicję zaproponował Lionel Robbins, który dla ekonomii wyznaczył zadanie zbadania tych aspektów ludzkiego zachowania, które dotyczą związku między celami a ograniczonymi środkami mającymi alternatywne zastosowania (Godłów-Legiędź, 2012, s. 75). Jeszcze dalej w swych propozycjach poszedł D. Rosse, wyznaczając ekonomii zadanie badania zachowania systemów, a nie zachowania ludzi (Wojtyna, 2009, s. 32).

Tego rodzaju zabiegi zmierzały do oddalenia ekonomii od ekonomii klasycznej, co przy towarzyszącej temu fascynacji osiągnięciami i statusem matema- 
tyki doprowadziło ekonomię głównego nurtu do rewolucji formalistycznej na przełomie lat 50. i $60 . \mathrm{XX}$ w. Istotę tej rewolucji stanowiły wysoki poziom abstrakcyjności rozważań oraz zastosowanie matematyki i dedukcji w wyjaśnianiu zjawisk ekonomicznych. Ekonomiści formalistyczni, jak pisze Janina Godłów-Legiędź, nie posługują się po prostu matematyką jako narzędziem, lecz stosują matematykę jako model poznania naukowego, a za kryteria oceny badań ekonomicznych przyjmują kryteria matematyków. W rezultacie dokonują selekcji materiału badawczego z punktu widzenia jego przydatności do formalistycznego modelowania. Główną rolę w procesie formalizacji teorii ekonomicznej odegrali Kenneth Arrow i Gérard Debreu.

Abstrakcyjne, nierealistyczne założenia sprzyjały budowaniu eleganckich modeli, które miały szanse spodobania się matematykom. Problem jednak polegał na tym, że nie miały one wiele wspólnego z rzeczywistością ekonomiczną, której nie wyjaśniały i nie potrafiły przewidzieć. To zdominowanie głównego nurtu ekonomii przez sformalizowane modele wpłynęło zarówno na sam charakter nauki ekonomicznej, jak i na możliwość realizacji przez nią funkcji poznawczych i na jakość formułowanych teorii. W tej części rozważań pragniemy zwrócić uwagę na te koncepcje teoretyczne, które zainspirowane zostały dość powszechnym przekonaniem ekonomistów o przewadze ich metodologii i teorii oraz instrumentarium nad warsztatem pozostałych nauk społecznych. Wiara wielu ekonomistów w metodologiczny indywidualizm, w założenie o racjonalności podmiotów działających oraz fascynacja nierealistycznymi założeniami i teoriami ekonomicznymi stały się podstawą przekonania, że taka ekonomia stwarza najlepszą możliwość wyjaśnienia nie tylko zachowań ekonomicznych, ale i wszystkich pozostałych zachowań ludzkich. Gdyby to mogło okazać się prawdą, wtedy istnienie pozostałych nauk społecznych byłoby zbędne. Powodów zawłaszczania przedmiotów badań innych nauk bądź przyczyn przekonań o prymacie metodyki badań jakiejś dyscypliny nie należy szukać wyłącznie w emocjach ich przedstawicieli, lecz głównie w barierach stworzonych przez wybrane opcje metodologiczne. Ekonomia przyjęła sposób wyjaśniania nauk przyrodniczych i tzw. nauk ścisłych za swój wzorzec. Automatycznie więc zmuszona była przyjąć założenie o jedności nauki. A skoro inne nauki społeczne nie podzielały tego przekonania, to powstałby impas. Zatem aby impas ten przezwyciężyć, należało włączyć do ekonomii:

- sferę polityczną, działania partyjne, wyborcze...;

- problemy prawnicze, przestępstwa, pornografię, prostytucję;

- kwestie socjologiczne, problemy rodzinne, związki międzyludzkie, imigracje...;

- problemy pedagogiczne;

- psychologiczne itd. 
Tylko wtedy bowiem byłaby szansa na stworzenie jednej, zunifikowanej teorii ekonomii, a w dalszej kolejności jednolitej, zunifikowanej teorii społecznej (Brzeziński, Gorynia, Hockuba, 2009, s. 204). Zawłaszczając inne przedmioty badań, ekonomiści liczyli na uzyskanie legitymizacji do wypowiadania się w imieniu całej nauki społecznej i w ten sposób w połowie XX w. ekonomia znacząco poszerzyła swój zakres.

Przejmowanie przedmiotów badań nauk społecznych przez ekonomię rozpoczęło się od ogłoszenia przez Theodora Schulza teorii kapitału ludzkiego w $1960 \mathrm{r}$. Teoria ta dowodzi, że ludzie, wydając na siebie pieniądze, liczą przede wszystkim na przyszłe zyski o charakterze pieniężnym i pozapieniężnym, czyli wydatki te nie mogą być traktowane jako konsumpcja, lecz jako inwestycja. W latach 80 . XX w. okazało się, iż teoria kapitału ludzkiego nie wniosła niczego nowego do kwestii kształcenia i szkolenia zawodowego (Blaug, 1995, s. 304, 320). Mimo tego postanowiono rozszerzyć zakres wykorzystania aparatury i teorii ekonomicznych do wyjaśnienia funkcjonowania rodziny, małżeństwa i rozwodów.

Chicagowska nowa ekonomia domu (new home economics) nakazuje traktować rodzinę nie jako jednoosobowe gospodarstwo domowe, lecz jako wieloosobową jednostkę produkcyjną, maksymalizującą funkcję produkcji, której nakładami są dobra rynkowe, a także czas, kwalifikacje i wiedza poszczególnych jej członków. Jest to ewidentny przykład przejęcia problemów badawczych, tradycyjnie badanych przez socjologię, psychologię czy antropologię społeczną, przez ekonomię, czyli rozszerzenie pola zastosowania standardowych narzędzi mikroekonomii. Teorie te operują kategorią „rynku małżeństw”, na którym kobiety i mężczyźni konkurują między sobą, poszukując partnera. Rynek ten może być zrównoważony, gdy wszyscy znajdują partnera, lub niezrównoważony, gdy występują osoby, które nie zawarły małżeństwa. Zysk z małżeństwa zależy od urody, inteligencji i wykształcenia, te cechy bowiem wpływają na produktywność działań zarówno nierynkowych, jak i rynkowych. Z kolei za pomocą teorii komparatywnej D. Ricardo można wytłumaczyć podział obowiązków domowych między mężem a żoną. Teoria małżeństwa Gary’ego Beckera próbuje wyjaśnić przewagę monogamii nad poligamią tym, że jest ona bardziej efektywna i odwołuje się ona do tego, iż przyrosty produkcyjności będące wynikiem łączenia się kobiet i mężczyzn w gospodarstwo domowe podlegają zjawisku malejących przychodów. Ekonomiści głoszą, iż podejście ekonomiczne góruje nad dowolnym innym podejściem, ale nigdy nie dokonują konkretnych porównań $\mathrm{z}$ alternatywnymi podejściami badawczymi (Blaug, 1995, s. 326-331).

Nie należy kwestionować, że takie rozciągnięcie i wykorzystanie „logiki ekonomicznej” do analizowania problemów społecznych może być inspirujące, może być heurystyką, ale nie może zastąpić analizy, która obejmuje nie tylko materię, ale także zjawiska pozamaterialne, takie jak sensy, znaczenia, wartości. 
Nie znajdujemy zatem żadnego uzasadnienia dla zjawiska „imperializmu ekonomicznego", które zakłada, że ekonomia potrafi wyjaśnić wszystkie zachowania ludzkie, a nie tylko zachowania ekonomiczne.

\section{Eklektyzm metodologii ekonomicznej i jego konsekwencje}

Ekonomiści, którzy zaakceptowali wyjątkowość ich nauki i sens posiadania własnej metodologii, musieli przyjąć pewne stanowiska, których uzasadnienie wymagało wręcz ekwilibrystycznych zabiegów. Niektóre z nich przedstawimy poniżej.

Pierwszy problem stanowi status ontologiczny przedmiotu badań. Akceptacja faktu, iż ekonomia ma przedmiot badań identyczny z naukami społecznymi i odmienny od statusu ontologicznego nauk przyrodniczych, byłaby nie do pogodzenia $z$ aspiracjami do naśladowania nauk przyrodniczych i fascynacją osiągnięciami matematyków i logików. Najpierw należało zatem zrobić wszystko, aby ekonomię z nauki normatywnej uczynić nauką nomologiczną, czyli przede wszystkim pozbawioną wartości. Nie ma bowiem możliwości uzyskania empirycznych danych o wartościach, a tym samym o sprawdzalności, o której mówią empiryści, wartości nie są bowiem dostępne zmysłom zewnętrznym (Sosenko, 2001, s. 18).

W głównym nurcie ekonomii, który postawił na wykrywanie zależności przyczynowych, nie widziano miejsca na badanie sensów, znaczeń i wartości, a także na wytyczanie celów i ideałów gospodarowania oraz na oceny rezultatów gospodarowania. Najlepiej zatem byłoby wyłączyć z ekonomii politykę gospodarczą, ta bowiem okazuje się celowa, powiązana z czyimś interesem, uwikłana $\mathrm{w}$ politykę. $\mathrm{Z}$ tego punktu widzenia $\mathrm{w}$ głównym nurcie ekonomii nie powinno być miejsca dla twórczości J.M. Keynesa, gdyż ta nie jest w pełni teorią; przypomina raczej wkład $\mathrm{w}$ wiedzę politologiczną Niccola Machiavellego z tą różnicą, że jeden udzielał rad księciu, a drugi - rządom (Keynes, 1956, s. 25).

Mimo iż udowodniono, iż wręcz niemożliwe jest wyodrębnienie ekonomii wolnej od wartości, to większość ekonomistów nie przyjmuje tego do wiadomości. I nawet autorytet Gunnara Myrdala czy Roberta L. Heilbronera i ich jasne przekonanie, iż nie sposób rozróżnić ekonomii pozytywnej, która zajmuje się faktami, od normatywnej, uwikłanej w wartości, niczego nie zmieniły.

W literaturze ekonomicznej podejmowano liczne próby podziału ekonomii na tę lepszą - statusem ontologicznym zbliżoną do przedmiotu nauk przyrodniczych - i tę gorszą, która ma inny status ontologiczny. Mianowicie W. Nassau Senior i J.S. Mill zaproponowali podział ekonomii na "naukę" i „sztukę”. Keynes podzielił ekonomię polityczną na "naukę pozytywną", „naukę normatywną" 
oraz „sztukę", a L. Walras i V. Pareto zaproponowali podział na „ekonomię czystą” i „ekonomię stosowaną". Chociaż według Pareto ekonomia czysta nie może rozwiązać żadnego problemu. I mimo że tzw. ekonomię dobrobytu określił jako jawnie i bezwstydnie normatywną, to i tak istnieli tacy ekonomiści, którzy powołując się na niego, traktowali teorię dobrobytu jako gałąź pozytywnej ekonomii (Blaug, 1995, s. 188-192).

Innym problemem, nad którym ekonomiści przechodzą bezrefleksyjnie, jest związek między rzeczywistością badaną a rzeczywistością realną. Skoro rzeczywistość realna nie nadaje się do wyjaśniania dedukcyjno-nomologicznego oraz modelowania matematycznego, to należy ją zmienić przez przyjęcie pewnych założeń. Ale wtedy mamy do czynienia z czymś wymyślonym, hipotetycznym, umownym, z czymś, co jest zbliżone do przedmiotu badań matematycznych, co może być zakwalifikowane jako część logiki. D. Warswick stwierdził: „istnieją dziś całe gałęzie abstrakcyjnej teorii ekonomicznej, które nie mają żadnego związku z realnymi faktami i są niemalże niemożliwe do odróżnienia od czystej matematyki" (Blaug, 1995, s. 343).

Powszechnie przyjmowane są abstrakcyjne oderwane od rzeczywistości założenia: o „wolnym rynku”, o „konkurencji doskonałej”, o „doskonałej mobilności środków produkcji i siły roboczej z jednej gałęzi do drugiej”, o „racjonalności działania podmiotów”, o „pełnej informacji rynkowej” itd. Jeżeli do tego dodamy jeszcze często wykorzystywane założenia typu constans czy ceteris paribus, to nic dziwnego, iż modele matematyczne opisują czy wyjaśniają fikcyjną rzeczywistość i nie nadają się do prognozowania czy przewidywania. Mimo to autorytety ekonomiczne bronią prawa do formułowania założeń teorii niezgodnych z rzeczywistością. Co więcej, Milton Friedman uznaje, że zaletę założeń stanowi to, że nie są one realistyczne, czyli mogą być fałszywe jako opis. Wystarczy według niego, gdy założenia przypisują podmiotom gospodarczym motywacje, które są uświadamiane. Kazimierz Sosenko stwierdza, że założenie, które można uznać za realistyczne, musi zawierać jasny sens tego, co głosi, oraz być zgodne z faktami (Sosenko, 2001, s. 19).

Kolejny problem stwarza ekonomistom opowiedzenie się za dualizmem metodologicznym, a odrzucenie monizmu. Mimo iż wielu ekonomistów dostrzega, że każde zjawisko ekonomiczne ma własny sens, którego nie da się zredukować do cech materii, to nie mogą wyrzec się monizmu, ponieważ byłoby to równoznaczne z rezygnacją dorównania naukom przyrodniczym, a tego główny nurt nie chce. Ekonomiści głównego nurtu starają się też nie dostrzegać, że język ekonomiczny nie jest aksjologicznie neutralny. Takie pojęcia, jak: zysk, strata, efektywność itd., okazują się obciążone wartościami, ale i to nie stanowi bariery, jak stwierdzają bowiem niektórzy, wystarczy, że pojęcia obciążone wartościami są dobrze zdefiniowane. Jeżeli do tego dodamy, iż w ekonomii wykorzystuje 
się powszechnie „typy idealne”, np. homo economicus, które traktuje się nie jako konstrukcje myślowe, lecz jako aprioryczną prawdę, jako fakt potwierdzany codziennym doświadczeniem, to łatwiej nam zrozumieć stopień oddalenia analiz ekonomicznych od realiów.

Ekonomiści głównego nurtu opowiadają się za indywidualizmem metodologicznym. Automatycznie dystansują się wobec holizmu, a to oznacza, że w ekonomii nie powinno być miejsca dla makroekonomii. Dorobek J. Keynesa też znalazłby się poza tak programowaną nauką ekonomii. Indywidualizm metodologiczny wychodzi z założenia, że wszelkie działania są działaniami jednostek, a byty kolektywne, takie jak społeczeństwo, grupa społeczna, nie istnieją realnie i są pojęciami abstrakcyjnymi. Holizm metodologiczny - odwrotnie. W skrajnej postaci wręcz kwestionuje istnienie jednostek. Twierdzi, że kolektywne całości istnieją niezależnie od budujących je jednostek, a całości są ważniejsze od ich składowych (von Mises, 2007, s. 36).

Według L. Misesa, twórcy prakseologii, celowa działalność jednostki stanowi absolutnie konieczny warunek wszelkiego zachowania (nie tylko ekonomicznego), tworząc w rzeczywistości niewymagającą dalszego uzasadnienia syntetyczną zasadę a priori (Blaug, 1995, s. 135). Stosunek nauk społecznych do indywidualizmu metodologicznego z natury rzeczy nie może być identyczny, o ile bowiem chętnie przyjmują go psycholodzy, to już dla socjologii czy politologii stwarza poważne problemy ze zdefiniowaniem przedmiotu ich badań. Ekonomiści, którzy optują za indywidualizmem, próbują uzasadnić całości społeczne tym, że przy dużej liczbie obserwacji jednostkowych zachowań można uzyskać wiedzę na temat tego, jak zachowują się całości społeczne. Papierkiem lakmusowym przy rozstrzyganiu tego, z jakimi naukami - przyrodniczymi czy społecznymi dana dyscyplina się identyfikuje, jest jej stosunek do koncepcji Verstehen. Zgodnie $\mathrm{z}$ hermeneutyką Wilhelma Diltheya oraz Maxa Webera życie duchowe możemy zrozumieć, „naturę” natomiast mamy szansę wyjaśnić. Czyli według W. Diltheya rozumienie jest typowym dla nauk humanistycznych sposobem poznania przeciwnym ścisłemu i analitycznemu wyjaśnianiu, to także pierwotna postawa istoty ludzkiej wobec otaczającego ją środowiska (Paczkowska-Łagowska, 2000, s. 87). Istotą rozumienia jest poznanie sfery wewnętrznej na podstawie znaków z zewnątrz dostarczanych przez zmysły. A więc rozumienie to poznanie motywów, celów, dążeń, postaw, wartości, którymi kieruje się działający podmiot. Z kolei rozumienie utrwalonych przejawów życia nazywamy wykładnią albo interpretacją. Interpretacja polega zatem na wydobyciu z dzieł sensu i przełożeniu go na język komunikacji (Markowska, 2007, s. 67). W sferze społecznej na ogół trudno jest mówić o pewnej powtarzalności zdarzeń, nawet w wypadku zapewnienia identycznych warunków. Do głosu dochodzą bowiem czynniki wolicjonalne, emocjonalne, etyczne czy aksjologiczne. Opowiedzenie 
się ekonomistów za koncepcją Verstehen byłoby równoznaczne z zachwianiem wiary w możliwości wyjaśniania zjawisk ekonomicznych za pomocą schematu dedukcyjno-nomologicznego, $\mathrm{z}$ akceptacją jednoznacznego zaliczenia ekonomii do nauk społecznych, a także $\mathrm{z}$ wyeliminowaniem $\mathrm{z}$ niej wszystkich twierdzeń makroekonomicznych.

Rozstrzygnięcia metodologiczne przyjmowane przez główny nurt (nurt większościowy ekonomistów) są bardzo krytykowane, ale krytycy stanowią zdecydowaną mniejszość i w dodatku ich wypowiedzi są przez tych pierwszych ignorowane. Przytoczymy kilka takich stanowisk, których ekonomiści z nurtu większościowego nie chcą dostrzec i przechodzą wobec nich bez pogłębionej refleksji. Milton Friedman, Fritz Machlup, Paul Samuelson bronią ekonomii przed uszczypliwą krytyką jej metodologicznych wyborów, stosując tzw. metodologię defensywną, chociaż zarzuty są dużego kalibru. Przykładowo Frank Knight odrzuca pogląd o tym, że prawda w ekonomii znaczy tyle samo co prawda w naukach przyrodniczych i że zachowania ekonomiczne mogą być testowane empirycznie, są one bowiem działaniami celowymi, a zatem ich interpretacja zależy od naszej intuicyjnej wiedzy na temat ich celów. Wahadło symbolizujące dyskusje o statusie ekonomii odchyliło się do tego stopnia, że zaprzeczono nawet twierdzeniu, iż ekonomia jest nauką i cała hipotetyczno-dedukcyjna tradycja teoretyzowania $\mathrm{w}$ ekonomii jest ślepą uliczką, a ekonomiści powinni porzucić mrzonki o autonomii swej dyscypliny. Z kolei Joan Robinson opisuje ekonomię jako po części naukowe studium społeczeństwa, po części zaś jako narzędzie służące propagowaniu ideologii.

W metodologii instytucjonalistów Hugh Ward porównuje rolę ekonomii do storytelling (opowiadanie bajek). Storytelling opiera się na metodzie, którą historycy nazywają „wiązaniem ze sobą" faktów, uogólnień, teorii i sądów wartościujących, której spójność zapewnia zbiór zakładanych milcząco przez autora przekonań i poglądów podzielanych przez czytelnika (Blaug, 1995, s. 142, 159, 167, $168,174)$. Tego typu stanowisko jest największą kapitulacją ambicji teoretyzowania w ekonomii. Skoro nie da się stworzyć teorii, to najlepsze, co można uczynić, to opowiadanie.

Jak widać, ekonomiści nie są zgodni w sprawach metodologii - nieliczni są otwarci na różne propozycje i wyciągają wnioski $\mathrm{z}$ analiz metodologicznych. Większość zaś nie ma zamiaru schodzić z drogi matematyzacji badań ekonomicznych w przekonaniu, że ten kierunek badań najlepiej zrealizuje funkcje nauki. A jakie są tego efekty? Przytoczymy opinie niektórych ekonomistów.

Współczesna gospodarka światowa i narodowa ukształtowana została w dużej mierze przez liberalizm i neoliberalizm, a więc doktryny stworzone głównie przez Friedricha Augusta von Hayeka i Miltona Friedmana. Zakłada ona, iż gospodarka jako całość może się sama regulować i z dobrym skutkiem obywa się 
bez ingerencji państwa. Teorie powstałe na podstawie neoliberalizmu, mimo iż nie sprawdziły się, były rozwijane i co więcej, ich autorzy byli wyróżniani, a nawet systematycznie przyznawano im Nagrodę Nobla. Na skutki nie trzeba było długo czekać. Świat po liberalizmie - pisze Marian Guzek, składa się ze zdeformowanych przez monopole spekulacyjne rynków finansowych oraz agencji ratingowych o cechach monopolistycznych (Guzek, 2012, s. 31). Wiara w agencje ratingowe oraz w możliwości wyceny ryzyka instrumentów finansowych i możliwości oceny kondycji finansowej była powodem iluzji, że wszystko znajduje się pod kontrolą i dopiero bieg wypadków, stwierdza J. Godłów-Legiędź, pokazał, że jest inaczej i że innowacje finansowe przyczyniły się do zwiększenia poziomu ryzyka w systemie ekonomicznym. Stworzono warunki do niczym nieograniczonego rozrostu sektora finansowego. Na tle realnej gospodarki oraz światowego PKB wartość aktywów finansowych rosła wręcz patologicznie. Mianowicie w roku 1980 wartość ich była zaledwie większa od światowego PKB o 19\%, w 1990 stanowiła już 220\% PKB, a przed kryzysem, w 2007 r., wartość aktywów finansowych stanowiła aż 340\% światowego PKB. Kryzys finansowy zredukował nieco wartość aktywów finansowych do poziomu 300\% PKB, ale już w latach 2009-2010 tempo ich wzrostu było trzykrotnie wyższe od tempa wzrostu światowego PKB (Godłów-Legiędź, 2012, s. 82-83). Spekulacyjne praktyki rynków finansowych, kreowanie pieniądza bez pokrycie w realnym majątku, duża skala zmian cen na rynkach towarowych spowodowana napływem kapitału $\mathrm{z}$ instytucji finansowych, towarzystw ubezpieczeniowych i funduszy emerytalnych spowodowały, iż informacje płynące $z$ rynków były mylące i wypaczały system cen oraz powodowały nieskuteczność mechanizmów dostosowawczych. Paradoksem jest to, że instrumenty, które uruchomiono po to, aby stabilizować ceny, kursy walut czy stopy procentowe, a przede wszystkim, aby zmniejszyć ryzyko, nie okazały się skuteczne i zostały wykorzystane w celach spekulacyjnych. Sprzyjało temu też powszechne zerwanie z zasadą, że zysk można wykazywać w sprawozdawczości finansowej wtedy tylko, gdy jest on zrealizowany w postaci sprzedaży (Godłów-Legiędź, 2012, s. 85, 87).

Duże możliwości kreowania zysków spekulacyjnych stwarza dynamicznie rozwijana agresywna inżynieria finansowa, inżynieria księgowa i intelektualna. Możliwość wyboru metod wyceny majątku stała się w rękach przedsiębiorców i instytucji finansowych narzędziem do kreowania odmiennych, bardzo różniących się od siebie obrazów sytuacji finansowej. Tego typu praktyki spowodowały pogłębienie się , asymetrii informacyjnej” między twórcami modeli i stosującymi je funduszami a ich klientami oraz między zarządami spółek a ich akcjonariuszami i klientami. A skoro wiedza i informacja nie są dostępne w jednakowym stopniu dla wszystkich uczestników transakcji finansowych, to uczestnicy transakcji rynkowych czy finansowych nie ponoszą jednakowego ryzyka. Możliwości 
stosowania kreatywnej wyceny czy kreatywnej księgowości faworyzują jednych, a dyskryminują pozostałych uczestników tzw. gry rynkowej (Godłów-Legiędź, 2012, s. 88). Wobec współczesnych problemów gospodarczych politycy, pisze A. Czarczyńska, są często bezradni, nie mają bowiem wsparcia w ekonomii. Przed rokiem 2008 powszechnie powoływano się na ogromną zgromadzoną wiedzę o gospodarce, która okazała się zasadniczo bezwartościowa wobec kryzysu finansowego i dlatego zaczęto coraz głośniej krytykować dotychczasowe metody analizy i stosowane instrumenty oddziaływania ekonomicznego. Krytycznie oceniano działalność instytucji finansowych i organizacji kontroli państwowej, krytykowano praktyki stosowane przez agencje ratingowe, które uwikłane w interesy manipulowały informacjami. Ogłoszono potrzebę powrotu do interwencjonizmu wobec ujawnionych słabości liberalizmu gospodarczego. Sfera społeczna opanowana przez gry różnych interesów od lat wymykała się spod kontroli społecznej. Negatywną rolę $\mathrm{w}$ tym procesie odegrali też politycy, których fundamentalnym zadaniem było pilnowanie, aby nie doszło w tej sferze do chaosu, a w rzeczywistości sami zaczęli go wywoływać, kupując głosy wyborców za pieniądze przyszłych pokoleń. Proces ten niestety trwa w dalszym ciągu, ponieważ nie ma woli dokonania zmian tej patologii wśród politycznych decydentów. Ci ostatni mają zresztą poparcie w tej sprawie znacznej części, głównie starszego pokolenia wyborców. W wyniku tych działań, obserwujemy wręcz „klasyczną piramidę finansową", która obciąży następne generacje. Wszystkie te zjawiska godzą także w autorytet nauk ekonomicznych (Czarczyńska, 2012, s. 145-146).

Zakres przypisywanej nauce ekonomicznej odpowiedzialności za zaistniałą sytuację jest różny. Niektórzy publicyści, jak np. Naomi Klein, uważają, że ekonomia ortodoksyjna (autorka utożsamia ją z poglądami M. Friedmana i szkoły chicagowskiej) jest wyłącznie odpowiedzialna za złą kondycję gospodarki (Klein, 2011, s. 15-17). Są jednak i zdecydowani obrońcy autorytetu ekonomii. Bogusław Fiedor, komentując opinie przedstawicieli nurtów heterodoksyjnych (ekonomii alternatywnej albo antyekonomii) o kryzysie ekonomii, twierdzi, że krytyka ta jest zbyt daleko posunięta, często nieuprawniona, a nawet krzywdząca dla ekonomistów i ich nauki. Zgadza się natomiast $\mathrm{z}$ tezą o kryzysie sposobu uprawiania ekonomii, o kryzysie w przestrzeganiu norm i wartości związanych z gospodarką rynkową oraz kryzysie wywołanym przez nieetyczne zachowania menadżerów wielkich firm, zwłaszcza finansowych. Fiedor, głosząc tezę, że ekonomia nie jest wcale ani „przed” ani „po” kryzysie, lecz w trakcie normalnego procesu rozwoju. W dalszych swych wywodach wskazuje jednak na pewne słabości procesów badawczych w ekonomii oraz na nowe zjawiska jakościowe, które powinny być uwzględnione w analizie ekonomicznej (Fiedor, 2010, s. 453, 458, 460). Z kolei Bartosz Scheuer sytuację kryzysową w ekonomii tłumaczy stagnacją $\mathrm{w}$ obszarze filozofii ekonomii i ekonomicznej metodologii i te 
czynniki czyni odpowiedzialnymi za ograniczony zakres propozycji teoretycznych i praktycznych (2012, s. 129). Halina Zboroń za najważniejszą przyczynę zjawisk kryzysowych w ekonomii uznaje brak zgody ekonomistów na zaliczanie ich nauki do nauk społecznych, czego konsekwencją jest pomijanie bądź lekceważenie uwarunkowań kulturowych w działaniach ekonomicznych oraz uczynienie przedmiotem swych badań takiego fragmentu rzeczywistości społecznej, który okazuje się nieprawdziwy bądź nieadekwatny (Zboroń, 2009, s. 14).

Bez względu na subiektywne oceny statusu ekonomii metodologiczna droga obrana przez główny nurt raczej nie spełniła pokładanych w niej nadziei. Ekonomia im bardziej starała się zbliżyć do science, tym bardziej odbiegała od realności, tworzyła modele i teorie, które w żaden sposób nie opisywały rzeczywistości, ale dzięki temu upodabniały się do matematyki i jako takie traciły szanse prognostyczne. Marzenie ekonomistów o tym, aby nadać badaniom nad zachowaniami ekonomicznymi rangę prawdziwej nauki, nie spełniło się, ponieważ nie udało się zastąpić fenomenalistycznego opisu teorią złożoną z systemu koherentnych praw przyczynowo-skutkowych o nietrywialnej, predykatywnej wartości. W tej sprawie nie podzielam opinii Francisa Fukuyamy, który uznał, że rynki poddają się tego typu analizie i dlatego ekonomia stała się królową nauk społecznych. Należy jednak zgodzić się z jego stwierdzeniem, że dążenie do większej naukowości ma swoją realną cenę - zamyka nam oczy na rzeczywistą złożoność, oraz że ekonomiści nie mogą sobie poradzić bez użycia argumentów z repertuaru politologii, takich jak komunikacja, perswazja, symboliczne zajmowanie oficjalnego stanowiska (Fukuyama, 2005, s. 99, 108). A zatem politolodzy „nie idźcie tą drogą", wybierzcie własną.

\section{Postulowane kierunki rozwoju politologii}

Powyższa analiza została przeprowadzona głównie po to, aby stworzyć podstawy do dyskusji nad kierunkami rozwoju politologii oraz jej metodologicznych, epistemologicznych i ontologicznych wyborów. Po wielu latach eksperymentowania w ekonomii czas wyciągnąć wnioski. Politolodzy poza nielicznymi wyjątkami przyznali, iż ich dyscyplina nie ma tożsamości metodologicznej, przedmiotowo-metodologiczna swoistość przysługuje bowiem całym dziedzinom nauki, i że osobliwą metodą nauk o człowieku jest interpretacja humanistyczna. Polega ona na wyjaśnianiu działań ludzkich i ich rezultatów przez odwoływanie się do celów działających podmiotów oraz ich wiedzy wskazującej, jakie środki są skuteczne w procesie osiągania owych celów. Zakłada ona też, że masowe zachowania ludzkie mają charakter racjonalny, tzn. stosują właściwe środki do osiągnięcia danych celów (Such, Szcześniak, 2006, s. 17). Jak stwierdził Jan 
Woleński, „różnice metodologiczne odnoszą się właśnie do grup dyscyplin, natomiast dyscypliny poszczególne różnią się technikami” (1981, s. 7). Nigdy również nie zgłaszano wątpliwości co do tego, iż jest ona nauką społeczną i jakie wynikają stąd konsekwencje badawcze.

Politolodzy stosunkowo wcześnie uświadomili sobie, że sami nie mogą wypracować ogólnej teorii społecznej, a nawet ogólnej teorii zachowań politycznych. Przyjmują dość zgodnie, iż nieważne jest to, czy teoria została sformułowana w ramach tej czy innej dyscypliny naukowej, istotne natomiast okazuje się to, jakie spełnia standardy, jaki ma zakres merytoryczny i czasowy. Stąd większe otwarcie politologów na wyniki badań innych dyscyplin oraz mała podatność na tzw. imperializm politologiczny. Zorientowanie politologii na rezultaty badań innych dyscyplin wynika $z$ przekonania, iż szanse na rzetelną wiedzę mają całe zespoły dyscyplin, a nie każda $\mathrm{z}$ nich $\mathrm{z}$ osobna.

Słusznie zatem Tadeusz Klementewicz problemy metodologiczne politologii sprowadza do uwzględniania wiedzy gromadzonej zarówno przez różne subdyscypliny politologiczne, jak i przez pozostałe nauki społeczne, oraz do umiejętnego łączenia warunków zewnętrznych działania z podmiotowością ludzi, którą determinują wiedza o warunkach oraz wyznawane wartości (Klementewicz, 2014, s. 273). Wreszcie politolodzy w pełni uświadamiają sobie, iż ich nauka nigdy nie będzie wolna od wartościowania, czyli jej charakter normatywny przyjmowany jest z pokorą. Według niektórych politologów to nie tylko cecha niezbywalna, ale taka, która wzbogaca politologię, zbliża ją do rzeczywistości i wyróżnia spośród tych dyscyplin, które próbują analizować społeczną rzeczywistość po wyeliminowaniu z niej wartościowań.

Różnice między ekonomią a politologią można widzieć w tym, jak zareagowały one na behawioryzm. Ekonomia dość entuzjastycznie, jak na swoje tradycje, przyjęła pojawienie się ekonomii behawioralnej, która wniosła znacznie bogatszy obraz zachowań ludzkich w zestawieniu z obrazem dotychczasowym. Wcześniejszy obraz zakładał bowiem, iż podmioty są dobrze poinformowane, że ich preferencje są właściwie uporządkowane i stabilne, że postępują one w sposób egoistyczny i wykalkulowany. Ta otwartość na behawioryzm wynikała też z tego, iż behawioryści zakładali możliwość wyjaśniania zachowań jednostkowych i zbiorowych, a jak wiadomo, w wyjaśnianiu zakorzeniona jest idea przyczynowości, tak bardzo ceniona przez ekonomistów (Sanders, 2006, s. 60). Zmodyfikowany przez psychologów obraz zachowań ludzkich w pewnym sensie dyskwalifikował dotychczasowy model zakładany przez ekonomistów. Wykazywał on bowiem, że opinie ludzi okazują się nieobiektywne, że ich preferencje jawią się jako plastyczne i niestabilne, że są oni często emocjonalni, impulsywni i wywołują skutki, które sami uważają za złe. A zatem model homo economicus i homo sapiens to dwie różne istoty (Wojtyna, 2009, s. 36-37). Ekonomię beha- 
wioralną traktowano więc jako tę, która poszerza przedmiot badawczy bez zmiany jego paradygmatu, jako propozycję konstruowania bardziej rozbudowanych modeli uwzględniających osiągnięcia badawcze psychologów. Niektórzy widzieli w ekonomii behawioralnej próbę przeprowadzenia fundamentalnej zmiany ekonomii polegającej na odrzuceniu przewrotu paretowskiego, który nastąpił w latach 30.-40. XX w., a który opierał teorię na zasadach racjonalnego wyboru i wyeliminował z ekonomii wszelki psychologizm (Wojtyna, 2009, s. 39).

Zupełnie odmiennie zareagowali na behawioryzm politolodzy. Propozycja Johna Watsona sprowadzająca się do obserwacji, pomiaru obiektu i pomiaru zmysłowo postrzegalnych działań oraz przewidywań na tej podstawie nie została zaakceptowana przez politologów. Jako pierwszy z krytyką wystąpił David Easton, który tak drastyczne wykluczenie $\mathrm{z}$ badań nad polityką wszelkich danych subiektywnych jako zmiennych uznał za nieuzasadnione. Krytyki nie zatrzymała nawet obiecana przez behawioralną teorię szansa na teorię ogólną będącą dedukcyjnym systemem pozwalającym z ograniczonej liczby założeń i aksjomatów wydedukować szeroki zakres empirycznie weryfikowalnych uogólnień (Porębski, 1996, s. 26 i n.).

Behawioryzm nie spełnił pokładanych w nim nadziei i nie zagroził wcześniejszym szkołom myślenia politologicznego, wprost przeciwnie, spowodował powrót do nich i zachęcił do krytycznej refleksji nad nimi. Zaowocowało to nowymi przemyśleniami w postaci neoinstytucjonalizmu, neobehawioralizmu, neomarksizmu oraz przyczyniło się do zmodyfikowania teorii racjonalnego wyboru, teorii interpretacjonistycznych, czy teorii normatywnych (Blok, 2013, s. 43).

Analogicznie jak na behawioryzm zareagowano na neoinstytucjonalizm, który w ekonomii reprezentowali m.in. Gunnar Myrdal, James K. Galbraith i Robert L. Heilbroner - kontynuatorzy dzieła Thorsteina Veblena. Zalecali oni ustanowienie „instytucji” podstawową jednostką badawczą i zastąpienie nią jednostki homo economicus, którą propagowała ekonomia konwencjonalna. Propozycja ta była dobrze przyjęta przez przynajmniej niektórych ekonomistów z nadzieją na poszerzenie nauki ekonomicznej o nowe obszary. Ponadto zalecano też uwzględnienie w analizie ekonomicznej czynników politycznych (R. Heilbroner) oraz otwarcie się ekonomii na wyniki badań prawa, socjologii, historii i psychologii. Niestety i te propozycje nie zmieniły głównego nurtu (Mazur, 1991, s. 319 i n.).

$\mathrm{W}$ politologii natomiast neoinstytucjonalizm wniósł pewne nowe spojrzenia na instytucje i organizacje, ale nie był propozycją, którą politolodzy mogliby zaakceptować na zasadzie wyłączności. Wprost przeciwnie, siłą nowego instytucjonalizmu okazują się jego różnorodność teoretyczna i propozycja pogłębienia analizy ważnego, ale niecałego zakresu politologii (Lowndes, 2006, s. 106). 
Reasumując, należy odnotować, iż analizowane w tym artykule dyscypliny naukowe rozwijały się, dokonując dość odmiennych wyborów metodologicznych. Ekonomia swymi wyborami ograniczyła sobie możliwość działania i postawiła się w sytuacji, w której główny nurt badawczy nie mógł, zgodnie ze swoimi założeniami, zaakceptować subdyscyplin $\mathrm{z}$ natury rzeczy uwikłanych $\mathrm{w}$ wartościowanie, takich jak polityka gospodarcza czy nawet makroekonomia. I gdyby nie cechujący ją eklektyzm, to subdyscypliny te powinny pozostać poza ekonomią (głównego nurtu). Na marginesie dominującego nurtu pojawiły się liczne głosy przypominające, że ekonomia jest i powinna pozostać nauką społeczną, że musi być otwarta na inne nauki i że samodzielnie nie potrafi sformułować wartościowych teorii, ale nie zdołały one zmienić charakteru głównego nurtu (Deszczyński, 2015, s. 324).

W przeciwieństwie do ekonomii politologia okazuje się bardziej przygotowana do analizowania rzeczywistości takiej, jaką ona jest, tzn. rzeczywistości uwikłanej w wartościowanie, w ideologię, w odmienne i zmienne interesy grupowe, w konflikty itd. Nieważne wydaje się bowiem, czyje to jest pole badawcze, lecz to, która dyscyplina lepiej sobie radzi z adekwatnym doborem metod, ze zrozumieniem czy wreszcie z wyjaśnianiem badanej rzeczywistości. Oczywiście tego typu otwarcie się politologii na analizowanie konkretnej rzeczywistości, często dynamicznie się rozwijającej wraz z jej uwarunkowaniami zewnętrznymi, uwikłanej w wartościowanie czy ideologię wymaga odpowiedniego jej przeprofilowania, a także odpowiedniego przygotowania kadr badawczych do tych zadań. Możliwe są różne scenariusze kształcenia politologów, jednym $\mathrm{z}$ nich powinno być pogłębienie kształcenia politologów w zakresie badania zjawisk ekonomicznych, polityki gospodarczej czy makroekonomii po to, aby dać im szanse badania i rozwiązywania problemów ekonomicznych rozumianych społecznie, a nie tylko technicystycznie czy matematycznie. Szczegóły tych scenariuszy powinny się stać przedmiotem dysputy naszego środowiska.

\section{Literatura}

Bartkowiak, R. (2011). Rozwój myśli ekonomicznej. Warszawa: Oficyna Wydawnicza SGH. Bevir, M., Rhodes, R.A.W. (2006). „Teoria interpretacjonistyczna”. W: D. Marsh, G. Stoker (red.). Teorie i metody w naukach politycznych, przeł. J. Tegnerowicz. Kraków: Wydawnictwo Uniwersytetu Jagiellońskiego.

Blaug, M. (1995). Metodologia ekonomii, przeł. B. Czarny przy współpr. A. Molisak. Warszawa: Wydawnictwo Naukowe PWN.

Blok, Z. (2013). „Drogi poszukiwania tożsamości 'nauki o polityce”. Przegląd Politologiczny, nr 4. 
Brzeziński, M., Gorynia, M., Hockuba, Z. (2009). „Ekonomia a inne nauki społeczne na początku XXI w. Między imperializmem a kooperacją”. W: B. Fiedor, Z. Hockuba (red.). Nauki ekonomiczne wobec wyzwań współczesności. Warszawa: Polskie Towarzystwo Ekonomiczne.

Czarczyńska, A. (2012). „Świat w obliczu zagrożeń totalnych a wizje ekonomii integralnej”. W: M. Guzek (red.). Ekonomia i polityka w kryzysie. Kierunki zmian w teoriach. Warszawa: Uczelnia Łazarskiego, Instytut Studiów Politycznych PAN.

Deszczyński, P. (2015). „Nauki ekonomiczne wobec problemów globalizacji gospodarki światowej”. W: B. Fiedor (red.). Nauki ekonomiczne: stylizowane fakty a wyzwania współczesności. Warszawa: Polskie Towarzystwo Ekonomiczne.

Fiedor, B. (2010). „Kryzys gospodarczy a kryzys ekonomii jako nauki”. Ekonomista, nr 4.

Fukuyama, F. (2005). Budowanie państwa. Władza i ład międzynarodowy w XXI wieku, przeł. J. Serwański. Poznań: Dom Wydawniczy Rebis.

Godłów-Legiędź, J. (2012). „Od dominacji metodologii ekonomicznej do kryzysu”. W: M. Guzek (red.). Ekonomia i polityka w kryzysie. Kierunki zmian w teoriach. Warszawa: Uczelnia Łazarskiego, Instytut Studiów Politycznych PAN.

Guzek, M. (2012). „Liberalizm synergiczny na tle sporów doktrynalnych i kryzysów”. W: M. Guzek (red.). Ekonomia i polityka w kryzysie. Kierunki zmian w teoriach. Warszawa: Uczelnia Łazarskiego, Instytut Studiów Politycznych PAN.

Kaczmarczyk, H. (2017). Szkoła austriacka w ekonomii i naukach społecznych, mises.pl/ pliki/upload/sa_ens_kaczmarczyk.pdf (dostęp: 22.01.2017).

Keynes, J.M. (1956). Ogólna teoria zatrudnienia, procentu i pieniądza, przeł. M. Kalecki, S. Raczkowski. Warszawa: PWN.

Klein, N. (2011). Doktryna szoku: jak współczesny kapitalizm wykorzystuje klęski żywiołowe i kryzysy społeczne, przeł. H. Jankowska [i in.]. Warszawa: Warszawskie Wydawnictwo Literackie Muza.

Klementewicz, T. (2014). „Poza kredowym kołem polityczności. Politologia jako wieloparadygmatyczna struktura wiedzy”. W: P. Borowiec, R. Kłosowicz, P. Ścigaj (red.). Odmiany współczesnej nauki o polityce, t. 1. Kraków: Wydawnictwo Uniwersytetu Jagiellońskiego.

Lange, O. (1975a). „Neoklasyczna szkoła w ekonomii”. W: O. Lange. Dzieła, t. 3: Ekonomia polityczna. Warszawa: Państwowe Wydawnictwo Ekonomiczne.

Lange, O. (1975b). „Metoda ekonomii politycznej”. W: O. Lange. Dzieła, t. 3: Ekonomia polityczna. Warszawa: Państwowe Wydawnictwo Ekonomiczne.

Lange, O. (1977a). „Nauka na zakręcie”. W: O. Lange. Dzieła, t. 6: Teoria programowania. Warszawa: Państwowe Wydawnictwo Ekonomiczne.

Lange, O. (1977b). „O zastosowaniu matematyki w ekonomii i planowaniu”. W: O. Lange. Dzieła, t. 6: Teoria programowania. Warszawa: Państwowe Wydawnictwo Ekonomiczne. 
Lowndes, V. (2006). „Instytucjonalizm”. W: D. Marsh, G. Stoker (red.). Teorie i metody w naukach politycznych, przeł. J. Tegnerowicz. Kraków: Wydawnictwo Uniwersytetu Jagiellońskiego.

Markowska, M. (2007). „Interpretacja jako rozumienie w ujęciu Wilhelma Diltheya”. Czasopismo Filozoficzne, nr 2, lipiec.

Mazur, M. (1991). „Metoda badawcza neoinstytucjonalizmu”. Ekonomista, nr 2 (3).

Mejbaum, W. (1995). Wyjaśnianie i wyjaśnienie. Zarys teorii eksplanacji. Szczecin: Fundacja im. Kazimierza Ajdukiewicza na rzecz Rozwoju Nauk Filozoficznych.

Mises, L. von (2007). Ludzkie działania - traktat o ekonomii, przeł. W. Falkowski. Warszawa: Fundacja Instytut Ludwiga von Misesa.

Nasiłowski, M. (2003). Zarys historii myśli ekonomicznej od XVIII do końca XX wieku. Warszawa: Wydawnictwo Key Text.

Paczkowska-Łagowska, E. (2000). Logos życia: filozofia hermeneutyczna w kregu Wilhelma Diltheya. Gdańsk: Słowo/Obraz Terytoria.

Porębski, L. (1996). Behawioralny model władzy. Kraków: Universitas.

Sanders, D. (2006). „Behawioralizm”. W: D. Marsh, G. Stoker (red.). Teorie i metody w naukach politycznych, przeł. J. Tegnerowicz. Kraków: Wydawnictwo Uniwersytetu Jagiellońskiego.

Scheuer, B. (2012). „Kryzys w teorii ekonomii jako źródło kryzysu gospodarczego”. W: M. Guzek (red.). Ekonomia i polityka w kryzysie. Kierunki zmian w teoriach. Warszawa: Uczelnia Łazarskiego, Instytut Studiów Politycznych PAN.

Sosenko, K. (2001). „Wyjaśnianie i rozumienie w ekonomii”. Zeszyty Naukowe, nr 576.

Spychalski, G.B. (2001). Zarys historii myśli ekonomicznej. Warszawa-Łódź: Wydawnictwo Naukowe PWN.

Such, J., Szcześniak, M. (2006). Filozofia nauki. Poznań: Wydawnictwo UAM.

Temkin, G. (2008). Dyskusje o gospodarce socjalistycznej Marks - Lange - Mises - Hayek. Warszawa: Wydawnictwo Polskiego Towarzystwa Ekonomicznego.

Wojtyna, A. (2000). Ewolucja keynesizmu a główny nurt ekonomii. Warszawa: Wydawnictwo Naukowe PWN.

Wojtyna, A. (2009). „Współczesna ekonomia - kontynuacja czy poszukiwanie nowego paradygmatu". W: B. Fiedor, Z. Hockuba (red.). Nauki ekonomiczne wobec wyzwań współczesności. Warszawa: Polskie Towarzystwo Ekonomiczne.

Woleński, J. (1981). „Dyscyplina naukowa a teoria naukowa”. Zeszyty Naukoznawstwa, nr 1-2.

Zboroń, H. (2009). Teorie ekonomiczne w perspektywie konstruktywizmu społecznego. Poznań: Wydawnictwo UE w Poznaniu. 


\section{Streszczenie}

Celem artykułu jest ukazanie odmiennych kierunków ewolucji metodologicznych, jakie przechodziły dwie dyscypliny społeczne: ekonomia oraz politologia. Źródłem skrajnie różnych decyzji metodologicznych podejmowanych przez reprezentantów "głównych nurtów" w tych dyscyplinach były odmienne strategie budowania tożsamości własnej dyscypliny oraz różnice w postrzeganiu przedmiotu badań nauk społecznych. Ekonomiści, zapożyczając instrumentarium badawcze od nauk formalnych, opowiadali się po stronie monizmu metodologicznego i konstruowali tożsamość dyscypliny w opozycji do pozostałych reprezentantów nauk społecznych. Politologia z kolei (świadoma specyfiki przedmiotu badań nauk społecznych) przyjęła perspektywę dualizmu metodologicznego, dlatego też swoją tożsamość budowała nie w opozycji, lecz w ramach jednej dziedziny nauk - wyposażonej we wspólne metody badawcze, choć poruszającej odmienne aspekty. W artykule opisano również współczesne skutki tych różnych wyborów metodologicznych: z jednej strony kryzys zdolności eksplanacyjnych i predyktywnych ekonomii, wywołany pogłębiającą się formalizacją stosowanych modeli badawczych; z drugiej strony obserwowany w politologii zwrot w stronę interpretacjonizmu, koncentrującego swoją uwagę na odczytywaniu sensów i motywacji działań ludzkich.

Słowa kluczowe: nauki społeczne, metodologia, wiedza naukowa, kryzys ekonomii, politologia 